\title{
Four levels of evaluation nurse training program on regional food
}

\author{
Quatro níveis de avaliação de um programa de treinamento de enfermeiras sobre alimentação regional \\ Cuatro niveles de evaluación de un programa regional de capacitación en enfermería de alimentación
}

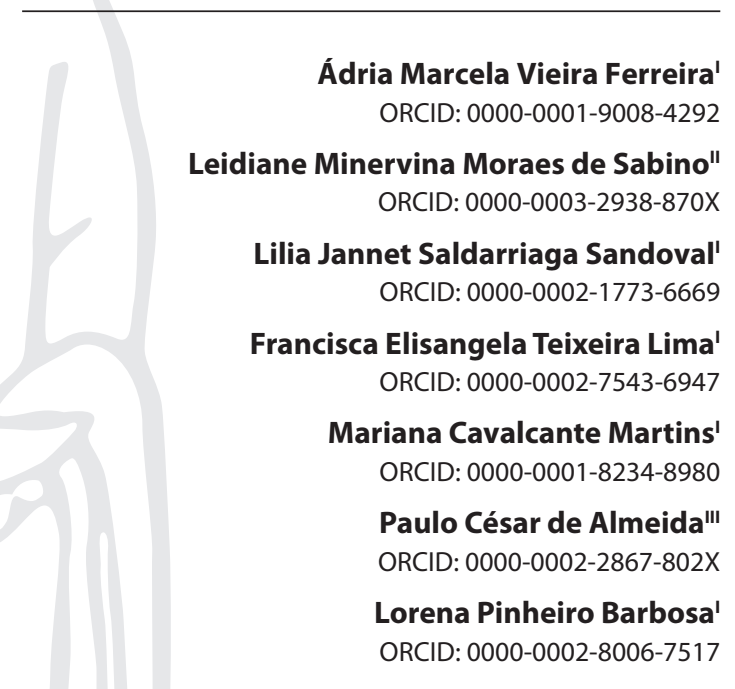

'Universidade Federal do Ceará. Fortaleza, Ceará, Brazil. "Universidade da Integração Internacional da Lusofonia AfroBrazileira. Fortaleza, Ceará, Brazil. "'Universidade Estadual do Ceará. Fortaleza-Ceará, Brazil.

How to cite this article: Ferreira AMV, Sabino LMM, Sandoval LJS, Lima FET, Martins MC, Almeida PC, et al. Four levels of evaluation nurse training program on regional food.

Rev Bras Enferm. 2020;73(Suppl 6):e20190745. doi: http://dx.doi.org/10.1590/0034-7167-2019-0745

Corresponding author:

Ádria Marcela Vieira Ferreira

E-mail: adriamarcela@hotmail.com

EDITOR IN CHIEF: Dulce Barbosa ASSOCIATE EDITOR: Alexandre Balsanelli

Submission: 01-13-2020

Approval: 07-04-2020

\section{ABSTRACT}

Objectives: to verify the effectiveness of a regional nutrition training program for nurses based on four levels of assessment: response, learning, behavior, and conclusions. Methods: this was a longitudinal, almost experimental before and after type of study, carried out in 2014 with eight nurses and 62 mothers attended in the Primary Health Care Units of the rural area of Ceará, Brazil, in a training program using educational technology on regional food. Results: the evaluations showed a positive reaction from the nurses; a very good post-test average (92.3\%); a change in nurses' behavior, verified by 30 educational activities after training; and satisfactory results, verified by improvement in knowledge, attitude and practice of the mothers about regional food and food safety after participating in the educational interventions carried out by the trained nurses. Conclusions: the training program was considered effective, showing positive results in the four levels of evaluation.

Descriptors: Educational Assessment; Food and Nutritional Education; Training; Health Promotion; Nursing.

\section{RESUMO}

Objetivos: verificar a efetividade de programa de treinamento de enfermeiras sobre alimentação regional com base em quatro níveis de avaliação: reação, aprendizagem, comportamento e resultados. Métodos: estudo quase experimental, longitudinal, do tipo antes e depois, realizado em 2014 com oito enfermeiras e 62 mães atendidas nas Unidades de Atenção Primária à Saúde da zona rural do Ceará, Brasil, em um programa de treinamento com uso de tecnologia educativa sobre alimentação regional. Resultados: as avaliações evidenciaram reação positiva das enfermeiras; média de acertos muito boa no pós-teste de conhecimento $(92,3 \%$,); mudança de comportamento das enfermeiras, constatada pela realização de 30 atividades educativas após o treinamento; e resultados satisfatórios, verificados pela melhora do conhecimento, atitude e prática das mães sobre alimentos regionais e segurança alimentar após participação nas intervenções educativas realizadas pelas enfermeiras treinadas. Conclusões: o programa de treinamento foi considerado efetivo, evidenciando resultados positivos nos quatros níveis de avaliação.

Descritores: Avaliação Educacional; Educação Alimentar e Nutricional; Capacitação; Promoção da Saúde; Enfermagem.

\section{RESUMEN}

Objetivos: verificar la efectividad del programa de entrenamiento de enfermeras sobre alimentación regional con base en cuatro niveles de evaluación: reacción, aprendizaje, conducta y resultados. Métodos: estudio casi experimental, longitudinal, del tipo antes y después, realizado en 2014 con ocho enfermeras y 62 madres atendidas en las Unidades de Atención Primaria a la Salud de la zona rural de Ceará, Brasil, en un programa de entrenamiento con uso de tecnología educativa sobre alimentación regional. Resultados: las evaluaciones evidenciaron reacción positiva de las enfermeras; media de aciertos muy buena en el post-test de conocimiento $(92,3 \%$,); cambio de conducta de las enfermeras, constatada por la realización de 30 actividades educativas después del entrenamiento; $y$ resultados satisfactorios, verificados por la mejora del conocimiento, actitud y práctica de las madres sobre alimentos regionales y seguridad alimentar después de la participación en las intervenciones educativas realizadas por las enfermeras entrenadas. Conclusiones: el programa de entrenamiento ha sido considerado efectivo, evidenciando resultados positivos en los cuatros niveles de evaluación.

Descriptores: Evaluación Educacional; Educación Alimentar y Nutricional; Capacitación; Promoción de la Salud; Enfermería. 


\section{INTRODUCTION}

The National Strategy for the Promotion of Breastfeeding and Healthy Complementary Feeding has as its objectives the qualification of breastfeeding and healthy complementary feeding promotion actions as well as the improvement of the competencies and skills of health professionals as a routine activity of the Basic Health Units (UBS) ${ }^{(1)}$.

Studies have emphasized the need for health professionals' improvement, because, in a systematic review regarding counseling on food for children under 2 years of age, it was discovered that out of 29 studies conducted in Brazil between 1998 and 2011, 18 were focused on training, highlighting the importance of those studies for improving the performance of professionals ${ }^{(2)}$.

The Health professionals informed difficulties in the development of food and nutrition educational actions ${ }^{(3)}$. Thus, a training program with Primary Health Care nurses on regional food can be an effective alternative for improving the professionals, in order to enable them to promote healthy and safe nutrition in families, ensuring adequate child growth and development.

Regional food is also encouraged by the Ministry of Health in the search for healthy eating, through the instruction manual "Brazilian Regional Foods", which provides a variety of fruits, vegetables, beans, roots, cereals and herbs available in each region, as well as suggests culinary preparations for the population ${ }^{(4)}$.

Therefore, it is appropriate not only to develop training programs, but also to verify their effectiveness. According to the Kirkpatrick model, evaluation of training programs can be carried out at four levels: reaction (evaluates participants' satisfaction with the training), learning (evaluates the change in knowledge), behavior (evaluates the professional's performance in his/her work environment) and outcome (verifies the tangible results of the program) $)^{(5)}$.

National and international surveys have been implementing training programs with nurses on various topics and conducting evaluations of reaction ${ }^{(6)}$, learning ${ }^{(7-8)}$, behavior $^{(9)}$ and results ${ }^{(10)}$.

It should also be noted that the use of more than one level of evaluation can show more consistent and comprehensive results. For example, in a training held in São Paulo with nurses on the systematic evaluation of pain in patients with morphine use, two levels of evaluation were used at the same time, and it was found that in addition to the change in the nurse's decision process for the dispensation of morphine (behavior), there was an impact on patients' pain relief (result) ${ }^{(11)}$.

\section{OBJECTIVES}

To verify the effectiveness of a regional feeding training program for nurses based on four levels of assessment: response, learning, behavior, and results.

\section{METHODS}

\section{Ethical Aspects}

The study was preceded by the approval of the Research Ethics Committee of the Federal University of Ceará and the signature off all nurses and mothers who participated in the study in the Free and Informed Consent Term.

\section{Design, period, and place of study}

Almost experimental, longitudinal, before-and-after-type study conducted in the Primary Health Care Units (UAPS) of a rural area in a municipality of the State of Ceará, Brazil, from September 2014 until March 2015.

The choice of the study site took into account that only $12 \%$ of this population living in rural areas had food security ${ }^{(12)}$, a concept defined as: constant access to food of sufficient quality and quantity by a population.

\section{Population or sample: inclusion and exclusion criteria}

The study population consisted of all 12 nurses working in the UAPS in the rural area of this region and the mothers of children assisted in these UAPS who participated in the educational intervention.

Among the 12 nurses, 9 were selected according to the following inclusion criteria: attend the first meeting of the training program. Participation of professionals in previous regional food training was adopted as exclusion criteria, with three nurses excluded. Also, one nurse was excluded by criterion of discontinuity since she asked to quit the UAPS where she worked after starting the program. Thus, the sample consisted of eight nurses.

Regarding the mothers, the sample was estimated for convenience, and from six to ten mothers were invited by each nurse to be on her group, so as to not compromise the effectiveness of the educational intervention. Thus, it was obtained a sample of 62 mothers, which met the following inclusion criteria: living in area of the study; having at least one child between 6 months and 6 years of age; and being attended at the UAPS where the nurses worked. Those who did not have telephone contact were excluded, since it was impossible to continue the evaluation after the educational intervention.

\section{Study protocol}

The data collection included stimulatingly the training program with the nurses (September to December 2014), composed of feedback, learning, and behavior evaluations; and the evaluation of results from the mothers who participated in the educational interventions conducted by the trained nurses (September 2014 to March 2015).

The nurses' training program followed the methodology of oral exposure dialogue and was developed in five meetings according to the schedule below.

Most of the meetings lasted an average of 50 minutes, with the exception of educational technology workshops, which lasted four hours, and the educational interventions, which lasted an average of 25 minutes. The educational technology used in the program was the validated serial album "Regional foods promoting food security", which consists of seven illustrations, which should be exposed to the target audience, and six worksheets, which guide the professional and address the themes: food and nutritional security; regional food; food hygiene; and regional recipes for cashew, banana, pumpkin and seriguela [cirguela] ${ }^{(13)}$. 
Chart 1 - Schedule of regional food nurse training program, Maranguape, Ceará, Brazil, 2014

\begin{tabular}{|c|l|}
\hline Meetings & Program \\
\hline $\begin{array}{c}1^{\text {st }} \text { meeting } \\
\left(1^{\text {st }} \text { week }\right)\end{array}$ & $\begin{array}{l}\text { - Application of pre-test knowledge in nurses. } \\
\text { - Workshop for the use of educational technology on } \\
\text { regional food. }\end{array}$ \\
\hline $\begin{array}{c}2^{\text {nd }} \text { meeting } \\
\left(2^{\text {nd }} \text { to }\right. \\
\left.5^{\text {th }} \text { week }\right)\end{array}$ & $\begin{array}{l}\text { - Field activity: Educational intervention carried out by } \\
\text { each nurse trained at UAPS in which she worked with } \\
\text { the selected mothers. }\end{array}$ \\
\hline $\begin{array}{c}3^{\text {rd }} \text { meeting } \\
\left(6^{\text {th }} \text { week }\right)\end{array}$ & $\begin{array}{l}\text { - Round of conversation on educational interventions. } \\
\text { - Delivery of the nurses' journal's follow-up to be used } \\
\text { within } 30 \text { days. }\end{array}$ \\
\hline $\begin{array}{c}4^{\text {th }} \text { meeting } \\
\left(10^{\text {th }} \text { week }\right)\end{array}$ & $\begin{array}{l}\text { - Round of conversation based on the journal's } \\
\text { follow-up used in the previous month and discussion } \\
\text { of selected scientific articles about the topic. }\end{array}$ \\
\hline $\begin{array}{c}5^{\text {th }} \text { meeting } \\
\left(13^{\text {th }} \text { week }\right)\end{array}$ & $\begin{array}{l}\text { - Initial feedback on mothers' } k \text { nowledge, attitude, and } \\
\text { practice one month after the educational intervention. } \\
\text { - Application of the post-test knowledge and reaction form } \\
\text { to the training program with nurses. }\end{array}$ \\
\hline
\end{tabular}

It is noteworthy that the workshops - tasting of regional recipes, demonstration of the application of technology and simulation activity (first meeting); and educational interventions performed by trained nurses (second meeting) - were developed by the researcher in a previous study ${ }^{(14)}$. However, only two levels of training evaluation were utilized: reaction evaluation and evaluation of the nurses' behavior regarding their performance and aptitude for application of educational technology.

In turn, in this study, the training program was continued to allow the use of the four levels of evaluation. The reaction's evaluation occurred again to verify the nurses' satisfaction with the program as a totality ( 12 weeks), being carried out based of a form containing seven open questions that addressed: workload adopted, methodology used in all meetings, satisfaction with the educational technology used and suggestions for its improvement.

In the learning evaluation of nurses, the pre-test and post-test were knowledge previously validated with content validity index of 0.95 and 0.94 , respectively ${ }^{(15)}$, which are composed of 13 questions addressing the themes of the serial album. The pre-test has an objective character, in which each question has four answer options, and only one alternative must be marked as correct. And the post-test presents affirmatives that should be classified by the nurse as "correct" or "incorrect". In the case of questions considered incorrect, the nurse should correct them on the corresponding lines.

For the classification of the theoretical knowledge of nurses, the following parameters were established: less than $50 \%$ of the questions - not acceptable; between $50 \%$ and $75 \%$ - acceptable; between 76 and $90 \%$ - good; and greater than $91 \%$ - very good ${ }^{(11)}$.

The evaluation of nurse's behavior was done by reading the monitoring journal follow-up, aiming to see the change in behavior of professionals in their daily lives on the long term. The journal was built by the researcher to be used by nurses for a period of one month, and was composed by topics that directed professionals to note relevant information about the use of educational technology in their work environment, such as the number of participants, and advantages and disadvantages presented.

Finally, the educational interventions substantiated the evaluation of results. For this purpose, two trained collaborators applied the sociodemographic form and the Knowledge, Attitude and Practice survey (KAP) with the mothers before the intervention, immediately after the intervention and one month, three months and six months after the intervention, by telephone contact.

It is worth noting that, in case of difficulty in establishing telephone contact, the mothers should return the call daily up to 45 days after the intervention, otherwise after this period, the mothers who did not answer were removed from the subsequent stages of result evaluation. Therefore, at the first moment, the sample consisted of 62 mothers, had a progressive decrease of this quantity within one month $(n=44)$, three months $(n=28)$ and within six months $(n=23)$ of follow-up.

The current KAP survey on regional foods was prepared and validated by two experts in the area and a pilot test performed with 15 family members in previous research. It consisted of 10 questions divided into the three axes (knowledge, attitude and practice), which can be classified as appropriate or inappropriate after response from the participants ${ }^{(13)}$.

For the axes to be taken as applicable, each one should be considered as specified in Chart 2.

Chart 2 - Description of responses considered applicable in the regional food knowledge, attitude, and practice axes

\begin{tabular}{|c|l|}
\hline Axes & \multicolumn{1}{|c|}{ Applicable } \\
\hline Knowledge & $\begin{array}{l}\text { - Have heard of regional foods and know what they } \\
\text { are for; } \\
\text { - Cites at least three types of those foods; } \\
\text { - And mentions at least two types of preparation } \\
\text { options using those foods. }\end{array}$ \\
\hline Attitude & $\begin{array}{l}\text { - Knows the importance of introducing regional } \\
\text { foods into a child's food routine; } \\
\text { - Highlights the benefits of this diet: preventing } \\
\text { malnutrition and obesity; promoting food security; } \\
\text { and/or being a new food alternative. }\end{array}$ \\
\hline Practice & $\begin{array}{l}\text { - Mention having already offered the child some } \\
\text { regional food; } \\
\text { - Accepts that this food may be included whenever } \\
\text { it is considered necessary. }\end{array}$ \\
\hline
\end{tabular}

Source: Martins et al., 2015.

\section{Analysis of results and statistics}

The Statistical Package for the Social Sciences (SPSS Inc., Chicago, United States), version 20.0 was used to analyze the information. The data were organized in tables, and the exploratory analysis occurred by absolute and relative frequencies. The Wilcoxon test was used to analyze the difference in scores between pre-test and post-test nurses' knowledge. Cochrane's Q statistical test was performed to verify the association and/or correlation of mothers' knowledge, attitude, and practice within the timing of the KAP survey.

\section{RESULTS}

All eight trained nurses were female. The average age was $32+10.4$ years. Regarding academic title prevailed broad sensu specialization $(6 ; 75 \%)$ and Primary Health Care $(5 ; 62.5 \%)$. Although they did not have previous training in the same subject, six nurses (75\%) reported having some knowledge about regional food; and four (50\%), on food and nutritional safety. 
Regarding the nurses' reaction by reading their reports, there was a positive reaction to all the meetings of the training program. The nurses found it appropriate to develop the program in five meetings, covering 13 weeks.

Regarding the technique of group discussion held between the nurses and the researcher at the third and fourth meetings, all nurses agreed that this teaching strategy enabled better learning about the proposed content and provided an opportunity to exchange personal experiences.

The nurses were pleased to apply the serial album "Regional foods promoting food safety" with the mothers in the UAPS, highlighting in their perceptions that educational technology promoted greater integration, participation and learning of mothers during the activity. Only two participants in the program made suggestions for improvement: inclusion of more recipes and a broader approach on food hygiene.

The learning evaluation pointed to important changes in nurses' knowledge after the training, although not statistically significant (Table 1).

Table 1 - Number of scores on pre and post-test nurses' theoretical knowledge, Maranguape, Ceará, Brazil, 2014

\begin{tabular}{cccc}
\hline Nurses & $\begin{array}{c}\text { Pre-test } \\
\text { N (\%) }\end{array}$ & $\begin{array}{c}\text { Post-test } \\
\mathbf{N}(\%)\end{array}$ & $\boldsymbol{p}^{\mathbf{a}}$ \\
\hline Nurse 1 & $13(100.0)$ & $12(92.3)$ & 0.999 \\
Nurse 2 & $13(100.0)$ & $13(100.0)$ & 1.000 \\
Nurse 3 & $12(92.3)$ & $11(84.6)$ & 0.999 \\
Nurse 4 & $9(69.2)$ & $13(100.0)$ & 0.523 \\
Nurse 5 & $9(69.2)$ & $11(84.6)$ & 0.824 \\
Nurse 6 & $8(61.5)$ & $12(92.3)$ & 0.503 \\
Nurse 7 & $11(84.6)$ & $11(84.6)$ & 1.000 \\
Nurse 8 & $12(92.3)$ & $13(100.0)$ & 0.999 \\
Average success & $10.8 \pm 1.9(83.6 \pm 15.8)$ & $12 \pm 0.9(92.3 \pm 7.1)$ & \\
\hline Note: $N=$ number of questions; a Wilcoxon Test. & \multicolumn{2}{l}{}
\end{tabular}

It is noticeable that nurses presenting good average scores already in the pre-test (10.8 \pm 1.9 questions and $83.6 \% \pm 15.8 \%)$, obtained an improvement of knowledge in the post-test $(12 \pm 0.9$ questions and $92.3 \% \pm 7.1 \%$ ), reaching a very good average scores.

The evaluation of nurses' behavior was checked from the follow-up journal. It was attested that the trained nurses took the educational technology, as they performed a total of 30 activities using the serial album, an average of 3.7 activities per nurse in a month, ranging from 2 to 8 for each nurse. Individual activities also prevailed $(25 ; 83.3 \%)$ in comparison to group activities $(5 ; 16.7 \%)$.

The nurses reported in the journal's follow-up and during the round of conversation that the individual interventions provided greater proximity and interaction between nurses and mothers. However, some mothers were anxious and with greater urgency to complete the educational activity.

In the case of group activities, the advantages of better use and discussion of the themes were highlighted, as well as the greater acceptance by some mothers who were more inhibited, who would not participate actively if they were carried out individually. On the other hand, the noise and dispersion of some participants were stressed as barriers, due to the presence of mothers with their children.

Before presenting the evaluation of the results of the program, the characteristics of the mothers who participated in the educational interventions should be highlighted. It was noted that mothers aged between 20 and 34 years (77.4\%), married (74.2\%), with more than ten years of study (56.5\%), only one child aged between 6 months and 6 years (83.9\%), with extra domiciliary work (66.1\%) and with a monthly income higher than a minimum wage $(65 \%)$.

To evaluate the results, the KAP Survey was applied to mothers before and after the educational intervention (Table 2).

Table 2 - Distribution of regional food knowledge, attitude, and practice axes during the time of application of Knowledge, Attitude and Practice survey, Maranguape, Ceará, Brazil, 2014

\begin{tabular}{|c|c|c|c|c|c|c|}
\hline & $\begin{array}{l}\text { Before } \\
N=62\end{array}$ & $\begin{array}{c}\text { After } \\
N=62\end{array}$ & $\begin{array}{c}1 \text { month } \\
N=44\end{array}$ & $\begin{array}{c}3 \text { months } \\
N=28\end{array}$ & $\begin{array}{c}6 \text { months } \\
N=23\end{array}$ & $p^{\mathbf{b}}$ \\
\hline \multicolumn{7}{|l|}{ Knowledge } \\
\hline Applicable & $0(0.0)$ & $50(80.6)$ & 40 (90.9) & 27 (96.4) & \multirow{2}{*}{$23(100)$} & \multirow{2}{*}{--} \\
\hline Not applicable & $62(100)$ & 12 (19.4) & $4(9.1)$ & 1 (3.6) & & \\
\hline \multicolumn{7}{|l|}{ Attitude } \\
\hline Applicable & 45 (72.6) & $58(93.5)$ & $38(86.3)$ & $25(89.3)$ & \multirow[t]{2}{*}{$23(100)$} & \multirow{2}{*}{0.186} \\
\hline Not applicable & $17(27.4)$ & $4(6.5)$ & $6(9.7)$ & $3(10.7)$ & & \\
\hline \multicolumn{7}{|l|}{ Practice } \\
\hline Applicable & $14(22.6)$ & 21 (33.9) & $24(54.5)$ & $14(50)$ & $15(65.2)$ & \multirow{2}{*}{0.022} \\
\hline Not applicable & 48 (77.4) & $41(66.1)$ & $20(45.5)$ & $14(50)$ & $8(34.8)$ & \\
\hline
\end{tabular}

Table 2 shows that the educational intervention provided an increase in the axes of knowledge, attitude, and practice of mothers on regional food, with statistical significance in the axes of practice $(p=0.022)$.

In the knowledge axes, no mother presented adequate knowledge before the intervention, but after the intervention this number increased gradually until it reached all mothers in the sixth month of evaluation, which made it impossible to calculate the level of significance between evaluations.

Regarding the attitude axes, it is noted that there was no statistically significant difference between the evaluations before and after the educational intervention $(p=0.186)$, however it is noted that, at all times after the intervention, this number was higher than $86.3 \%$, showing improvement in the attitude of mothers.

Finally, in the practice axes, a statistically significant difference was found between the evaluations before and after the educational intervention $(p=0.022)$. It is worth noting that, before the intervention, only $22.6 \%$ of the mothers presented the adequate practice, while this number reached $65.2 \%$ six months after the intervention.

\section{DISCUSSION}

In this survey, the evaluation according to reaction showed the nurses' satisfaction with the training program based on the positive evaluation regarding the methodological proposal and the educational technology adopted.

About the duration of the training, the nurses considered it sufficient to conduct it in 13 weeks. It is noticeable that there is a wide variation of time in the training sessions, from hours ${ }^{(16)}$ to weeks ${ }^{(6)}$. However, in three trainings developed at Brazilian health regulatory agency, the professionals though the training hours (between 8 hours and 20 hours) insufficient for the complexity and amount of content ${ }^{(16)}$. 
Thus, it is inferred that, although there is no precise recommendation on the workload, it is important to plan the courses considering the complexity of its contents, using more than one meeting whenever necessary.

In the present research, the strategies utilized in the field of continuing education in food and nutrition have included educational actions in groups and the use of active methodologies $^{(17)}$. The professionals consider the inclusion of exercises in the workshops, demonstrations of practical examples and group discussions as a facilitator to the teaching and learning process ${ }^{(6,16)}$.

Concerning the educational technology used in this study, the nurses emphasized that the series album "Regional foods promoting food security" is an innovative resource that favored the greater involvement and interaction of the users participating in the educational activity. This is due to the fact that the material in question was built in light of the liberating pedagogy of Paulo Freire, which encourages the use of problematizing and dialogic teaching techniques between educator and student ${ }^{(13)}$.

Thus, the importance of using problematizing pedagogies in the construction of educational technologies is reinforced, since, as shown by a concept analysis made with 13 articles on nursing educational technologies, the use of problematizing pedagogies is still insufficient since only one study adopted this teaching perspective ${ }^{(18)}$.

It is important to remember that in our first study, nurses were evaluated on their performance and aptitude to use the serial album in educational activities, the majority $(87.5 \%)$ being considered fit to perform effective interventions ${ }^{(14)}$.

In addition, the nurses suggested deepening the content of the serial album used in the training to address more recipes and aspects related to food hygiene. However, it is believed that such an increase may become stressful in the realization of educational activities, since, in this training, the nurses developed the activities in an average duration that has already reached 25 minutes.

On the other hand, it is considered relevant to update the serial album with regard to food hygiene, in view of the relevance of the theme of the families' food security. Furthermore, in a study developed in the Federal District, it was observed the low knowledge of mothers about food hygiene, because they reported using more often only water and soap ${ }^{(19)}$.

In the learning evaluation of this study, the nurses presented satisfactory results, considering that they achieved an incredibly good average score after the training. This corroborates recent research that developed training programs with nurses and also found positive results in learning evaluation ${ }^{(7)}$, although not always statistically significant ${ }^{(8)}$.

In the State of Minas Gerais, two types of learning evaluations were used before and after a theoretical-practical course in Basic Life Support, with 32 professionals, among them doctors and nurses. They had their theoretical knowledge evaluated by a test with 20 objective questions; and their technical skills, evaluated by a checklist in simulated care, so that the average score showed significant increase after training(7).

In a survey conducted in Kentucky with ten nursing interns, it was found that the average rate of learning and confidence of participants also improved after a training program on postoperative complications in an intensive care unit, but did not show statistically significant changes ${ }^{(8)}$.
Moreover, it is worth mentioning that, before the training of nurses in the present study, a good average score was already obtained. It is concluded that this previous satisfactory knowledge in nutrition can be influenced by factors such as the number of courses held during training, number of years working as a nurse, updating course on nutrition after graduation and receiving other kind of training ${ }^{(20)}$.

Therefore, even in the existence of a previous knowledge about regional foods and food and nutritional safety, an increase was verified with the application of the post-test, which demonstrates the importance of the implemented training program. Also, after analyzing the follow-up journals of the nurses, it was found that there was a change in their behavior, since they incorporated the educational practices in their work at the UAPS.

In line with this study, a quasi-experimental research developed at a university hospital in Turkey highlighted the extent of the behavior change in nurses after their participation in a training program on the need for greater use of the ventrogluteal area in safe drug administration. It was shown that, before training, $76.5 \%$ of nurses used the dorsal gluteal area; and only $7.4 \%$, the ventrogluteal area. Already four months after the training, the use of the dorsal gluteal area had decreased (48.1\%); and the ventrogluteal area had increased $(34.6 \%)^{(9)}$.

In view of these findings, it is opportune to emphasize the breaking down of some barriers in the incorporation of health education activities in the area of food and nutrition in Primary Care, because, according to the report of professionals who work in the UAPS in other studies, educational practices are generally related to chronic diseases and sexual and reproductive health ${ }^{(21)}$; and gives priority to age groups at higher risk, such as the elderly and pregnant women ${ }^{(22)}$.

Regarding the type of approach in the educational practices performed by nurses, although the individual approach prevailed in the present study, an integrative review on nursing practices with health education was found that nurses routinely perform health education activities in both individual and collective forms ${ }^{(23)}$. At the same time, it is opportune to clarify that the utilization of serial albums in educational activities can be effective both in individual interviews ${ }^{(24)}$ and in group sessions ${ }^{(25)}$.

Finally, the results of the nurses'training program were evaluated based on the impact on the population, because it is known that the success of the professionals' training must be directly related to improvements in their care practice ${ }^{(26)}$. Thus, the positive impact of the training program on the care practice of trained nurses was perceived by the improvements in the mothers' knowledge, attitude, and practice on regional food after the educational intervention implemented were verified, and in the evaluation of results.

A study conducted in Ethiopia corroborates these discoveries, since it has found significant increases in the knowledge, attitude, and practice scores of mothers after nutritional education on complementary feeding based on the addition of locally grown cereals and vegetables. In addition, significant improvements in the nutritional status of the children occurred in the intervention group ${ }^{(10)}$.

It is important to stress out that knowledge and adequate access to food determine healthy eating behavior ${ }^{(27)}$, but it is also necessary to consider the attitude of the individual, which refers to the intention to put knowledge into practice.

After the educational intervention in this study, as a high level of knowledge and appropriate attitude of mothers was obtained, 
Four levels to evaluate a nurse training program on regional food Ferreira AMV, Sabino LMM, Sandoval LJS, Lima FET, Martins MC, Almeida PC, et al.

a statistically significant increase in the practice of using regional foods was achieved. These results confirm that a high level of knowledge, especially of nutrition, considerably improves the criteria for food selection and forms the basis for an appropriate attitude towards healthy eating and later safe practice ${ }^{(28)}$.

Therefore, the training program has proved to be relevant as it has provided the opportunity for trained nurses to develop effective educational interventions that modify mothers' knowledge of regional foods, improving their understanding of the importance of introducing these foods into the child's dietary routine and directly influencing their increased use in infant food.

\section{Limitations of the study}

The absence of a control group is understood as a methodological limitation, as it is a quasi-experimental study. However, this was a conscious choice, considering the need to train all nurses working in the rural area of the municipality chosen.

\section{Contributions to the area of Nursing, Health or Public Policy}

It is believed that the training proposal undertaken will serve as a model for the development of other training programs in various topics aimed at the continuing education of professionals.

\section{CONCLUSIONS}

It is concluded that the training program was effective because the nurses obtained positive feedback, better learning and behavior change, and the mothers presented satisfactory results in the program based on adequate knowledge, attitude and practice after the intervention with the educational technology.

\section{FUNDING}

This research has received support from the National Council of Scientific and Technological Development (CNPq).

\section{REFERENCES}

1. Ministério da Saúde (BR). Estratégia Nacional para Promoção do Aleitamento Materno e Alimentação Complementar Saudável no Sistema Único de Saúde: manual de implementação [Internet]. Brasília: Ministério da Saúde (BR);2015 [cited 2019 Feb 02]. 154p. Available from: http://bvsms.saude.gov.br/bvs/publicacoes/estrategia_nacional_promocao_aleitamento_materno.pdf

2. Campos AAO, Cotta RMM, Oliveira JM, Santos AK, Araújo RMA. Nutritional counseling for children under two years of age: opportunities and obstacles as strategic challenges. Ciênc. Saúde Colet. 2014;19(2):529-38. doi: 10.1590/1413-81232014192.09642012

3. Pimentel VRM, Sousa MF, Hamann EM, Mendonça AVM. Food and nutrition in the Family Health Strategy in five Brazilian cities. Ciên Saúde Colet. 2014;19(1):49-57. doi: 10.1590/1413-81232014191.1901

4. Ministério da Saúde (BR). Secretaria de Atenção à Saúde. Departamento de Atenção Básica. Alimentos regionais brasileiros [Internet]. 2.ed. Brasília: Ministério da Saúde; 2015[cited 2019 Feb 02]. 486p. Available from: http://189.28.128.100/dab/docs/portaldab/publicacoes/livro_ alimentos_regionais_brasileiros.pdf

5. Kirkpatrick DL, Kirkpatrick JD. Como avaliar programas de treinamento de equipes- os quatro níveis. 1. ed. SENAC-RIO; 2010.

6. Lee RLT, Wang JJ. Effectiveness of an adolescent healthcare training programme for enhancing paediatric nurses' competencies. J Clin Nurs. 2016;25:3300-10. doi: 10.1111/jocn.13395

7. Meira LE Júnior, Souza FM, Almeida LC, Veloso GGV, Caldeira AP. Assessment of basic life support training for primary health care doctors and nurses. Rev Bras Med Fam Comunidade. 2016;11(38):1-10. doi: 10.5712/rbmfc11(38)1231

8. Boling B, Hardin-Pierce M, Jensen L, Hassan ZU. Evaluation of a High-Fidelity Simulation Training Program for New Cardiothoracic Intensive Care Unit Nurses. Semin. Thorac. Cardiovasc. Surg. 2016;28(4):770-5. doi:10.1053/j.semtcvs.2016.11.001.

9. Gülnar E, Özveren H. An evaluation of the effectiveness of a planned training program for nurses on administering intramuscular injections into the ventrogluteal site. Nurse educ today. 2016;36:360-3. doi: 10.1016/j.nedt.2015.09.001

10. Mulualem D, Henry CJ, Berhanu G, Whiting SJ. The effectiveness of nutrition education: applying the Health Belief Model in child-feeding practices to use pulses for complementary feeding in Southern Ethiopia. Ecol Food Nutr. 2016;55(3):308-323. doi: $10.1080 / 03670244.2016 .1161617$

11. Silva MAS, Pimenta CAM, Cruz DALM. Pain assessment and training: the impact on pain control after cardiac surgery. Rev Esc Enferm USP. 2013;47(1):84-92. Available from: 10.1590/S0080-62342013000100011

12. Aires JS, Martins MC, Joventino ES, Ximenes LB. Food (in)security in families of preschool children in a rural zone of Ceará. Acta Paul. Enferm. 2012;25(1):102-108. doi: 10.1590/S0103-21002012000100018

13. Martins MC, Ferreira AMV, Nascimento LAN, Aires JS, Almeida PCA, Ximenes LB. Influence of an educational strategy to promote the use of regional food. Rev Rene. 2015;16(2):242-9. doi: 10.15253/rev\%20rene.v16i2.2719

14. Ferreira AMV, Sabino LMM, Nascimento LA, Penha JC, Barbosa LP, Lima FET, et al. Analysis of the reaction and behavior of nurses after training on young child feeding. Rev Bras Enferm. 2019;72(Suppl 1):197-203. doi: 10.1590/0034-7167-2017-0529

15. Aires JS, Ferreira AMV, Sabino LMM, Oliveira EKF, Martins MC, Almeida PC, et al. Nurses' knowledge of the themes regional food and food security before and after trainning. Indian J Appl Res [Internet]. 2015 [cited 2019 Jan 22];5(2):685-687. Available from: http://www. repositorio.ufc.br/bitstream/riufc/15098/1/2015_art_jsaires.pdf 
Four levels to evaluate a nurse training program on regional food Ferreira AMV, Sabino LMM, Sandoval LJS, Lima FET, Martins MC, Almeida PC, et al.

16. Araujo MCDSQD, Abbad GDS, Freitas TRD. Avaliação qualitativa de treinamento. Rev Psicol Organ Trab. 2017;17(3):171-9. doi: 10.17652/ rpot/2017.3.13089

17. Ricardi LM, Sousa MFD. Educação permanente em alimentação e nutrição na Estratégia Saúde da Família: encontros e desencontros em municípios brasileiros de grande porte. Ciên Saúde Colet. 2015;20:209-18. doi: 10.1590/1413-81232014201.20812013

18. Afio ACE, Balbino AC, Alves MDS, De Carvalho LV, Santos MCL, Oliveira NR. Análise do conceito de tecnologia educacional em enfermagem aplicada ao paciente. Rev Rene. 2014;15(1). doi: 10.15253/2175-6783.2014000100020

19. Brasil GC, Ponce de Leon CGRM, Ribeiro LM,Schardosim JM, Guilhem DB. Conhecimento das mães sobre a alimentação de lactentes a partir dos seis meses de idade. Rev Min Enferm. 2017;21:e-998. doi: 10.5935/1415-2762.20170008

20. Mogre V, Yakubu A, Fuseini M, Amalba A, Aguree S. Nurses' knowledge and attitudes regarding malnutrition in children and its management in Ghana. Curationis. 2017;40(1):e1-e8. doi: 10.4102/curationis.v40i1.1618

21. Bezerra IMP, Machado MDFAS, Souza OFD, Antão JYFDL, Dantas MNL, Reis AOA, et. al. O fazer de profissionais no contexto da educação em saúde: uma revisão sistemática. Rev Bras Cresc Desenvolv Hum [Internet]. 2014[cited 2019 Feb 20];24(3):255-62. Available from: http:// pepsic.bvsalud.org/pdf/rbcdh/v24n3/04.pdf

22. Vieira FS, Portela NLC, Sousa GC, Costa ES, Oliveira DEP, Neiva MJLM. Inter-relação das ações de educação em saúde no contexto da Estratégia Saúde da Família: percepções do enfermeiro. Rev Pesqui: Cuid Fundam. 2017;9(4):1139-44. doi: 10.9789/2175-5361.2017.v9i4. $1139-1144$

23. Salbego LP, Silveira AD, Hammerschmidt KSDA. Práticas de enfermagem com educação em saúde no contexto familiar: revisão integrativa. Rev Enferm UFPE. 2014;8(12):4362-72. doi: 10.5205/1981-8963-v8i12a10184p4362-4372-2014

24. Javorski M, Rodrigues AJ, Dodt RCM, Almeida PC, Leal LP, Ximenes LB. Effects of an educational technology on self-efficacy for breastfeeding and practice of exclusive breastfeeding. Rev Esc Enferm USP. 2018;52:e03329. doi: 10.1590/S1980-220X2017031803329

25. Rodrigues AP, Dodt RCM, Oriá MOB, Almeida PC, Padoin SMM, Ximenes LB. Promoção da autoeficácia em amamentar por meio de sessão educativa grupal: ensaio clínico randomizado. Texto Contexto Enferm. 2017;26(4):e1220017. doi: 10.1590/0104-07072017001220017

26. Bays AM, Engelberg RA, Back AL, Ford DW, Downey L, Shannon SE, et al. Interprofessional communication skills training for serious illness: evaluation of a small-group, simulated patient intervention. J Palliat Med. 2014;17(2):159-66. doi: 10.1089/jpm.2013.0318

27. Reis LC, Correia IC, Mizutani ES. Stages of changes for fruit and vegetable intake and their relation to the nutritional status of undergraduate students. Einstein (São Paulo). 2014;12(1):48-54. doi: 10.1590/S1679-45082014AO2926

28. Silveira ML, Martins MC, Oliveira EKF, Joventino ES, Ximenes LB. Knowledge, attitude and practice on regional food among families of preschool children. Rev Rene[Internet]. 2014 [cited 201914 Jan];15(1):37-44. Available from: http://www.revistarene.ufc.br/revista/index. php/revista/article/view/1449/pdf_1 